\title{
The pathogenic potential of commensal species of Neisseria
}

\author{
AP JOHNSON \\ From the Division of Communicable Diseases, MRC Clinical Research Centre, Watford Road, Harrow, \\ Middlesex, HA1 3UJ
}

SUMmaRY Although Neisseria species other than $N$ gonorrhoeae and $N$ meningitidis normally comprise part of the commensal bacterial flora of the oropharynx, they may occasionally act as opportunistic pathogens. Infections in which these organisms have been implicated include cases of endocarditis, meningitis, septicaemia, otitis, bronchopneumonia and possibly genital tract disease. In this paper, the clinical and pathological features of such infections are described, together with a discusssion of factors that may contribute to their development.

In most textbooks of medical microbiology, the genus Neisseria is considered to contain only two pathogenic species, namely, $N$ gonorrhoeae and $N$ meningitidis. The other members of the genus are generally regarded as harmless inhabitants of the oropharynx. There is ample evidence in the literature, however, that these normally non-pathogenic species are capable of producing infection in a variety of anatomical sites including the heart, nervous system, bloodstream, respiratory tract and possibly the genital tract. Although the pathogenesis of gonococcal and meningococcal infections has been investigated extensively and is well documented, ${ }^{12}$ there is little collated information concerning infections produced by other Neisseria spp. This article is an attempt to remedy this deficiency.

\section{Classification of the genus Neisseria}

Any review of Neisseria infections is complicated by the fact that the classification of the organisms comprising the genus has undergone a number of changes over the years. A detailed discussion of the evolution of the taxonomy of the genus is beyond the scope of this article, but a brief optline, which conveys some idea of the degree of change is presented below. In the early part of this century, Gram-negative cocci were allocated a variety of generic and specific names including Micrococcus

Accepted for publication 20 October 1982 catarrhalis, $M$ cinereus, $M$ flavus, i, ii and iii, $M$ pharyngis siccus, Diplococcus mucosus and $D$ crassus. In an early review, Wilson and Smith ${ }^{3}$ considered the classification of these organisms to be unsatisfactory and suggested that apart from the meningococcus, all Gram-negative cocci found in the oropharynx should be classified as a single group called either $D$ pharyngis or $N$ pharyngis. This suggestion was not, however, generally adopted. In the 7th edition of Bergey's Manual of Determinative Bacteriology $y^{4}$ published in 1957, the genus Neisseria comprised 10 species (Tables 1 and 2). On the basis of subsequent studies of genetic homology between organisms, ${ }^{56}$ however, several of the species were reclassified, and the 8th edition of Bergey's Manual published in 1974, lists only six main species (Tables 1 and 2). The former species $N$ flava and $N$ perflava have been incorporated into the species $N$ subflava, while the former species $N$ catarrhalis and $N$ haemolysans have been transferred to the genera Branhamella and Gemella respectively. In addition, 10 species are mentioned, but because of the lack of relevant genetic data they are currently listed as species incertae cedis (Table 1).

In this review no attempt has been made to reclassify organisms described in early papers in terms of the currently used taxonomic scheme. Rather, the specific names used in each paper are given. However, the reader must bear in mind that the specific names used were determined by the classification scheme in vogue at the time each paper 
Table 1 Species of Neisseria listed in the 7th $(1957)^{4}$ and 8th (1974) ${ }^{7}$ editions of Bergey's Manual of Determinative Bacteriology

\begin{tabular}{|c|c|c|}
\hline 1957 classification $^{4}$ & \multicolumn{2}{|c|}{1974 classification $^{7}$} \\
\hline $\begin{array}{l}N \text { gonorrhoeae } \\
N \text { meningitidis } \\
N \text { flava } \\
N \text { perflava } \\
N \text { subflava } \\
N \text { sicca }\end{array}$ & \multicolumn{2}{|c|}{$\begin{array}{l}N \text { gonorrhoeae } \\
N \text { meningitidis } \\
N \text { subflava } \\
N \text { sicca } \\
N \text { mucosa } \\
N \text { flavescens }\end{array}$} \\
\hline N caviae & $\begin{array}{l}\text { Species incertae cedis } \\
N \text { animalis } \\
N \text { caviae } \\
N \text { cuniculi } \\
N \text { elongata } \\
\text { Novis }\end{array}$ & $\begin{array}{l}\text { N canis } \\
N \text { cinerea } \\
N \text { denitrificans } \\
\text { N lactamicus } \\
N \text { suis }\end{array}$ \\
\hline
\end{tabular}

was published, and that different authors who appear to be discussing the same species may not necessarily be referring to identical organisms.

\section{Infections produced by Neisseria organisms}

HEART INFECTIONS

Recorded cases of endocarditis produced by Neisseria organisms together with their clinical and pathological features are presented in Tables 3 and 4 respectively. A variety of Neisseria spp are documented as having caused endocarditis, although there are no recorded cases involving $N$ flavescens or $N$ lactamica, despite the fact that these organisms can cause meningitis and septicaemia (discussed below). As with endocarditis produced by other microorganisms-for example, Streptococcus viridanspatients generally presented with fever and malaise. Cardiac murmurs were nearly always present and the diagnosis was established by the repeated isolation of the micro-organism from the blood stream. Many patients developed petechiae, splinter haemorrhages and Osler's nodes (small tender nodules most frequently found on the finger or toe pads) which were probably manifestations of allergic vasculitis. Embolic episodes involving the right brachial and femoral arteries, ${ }^{25}$ the brain, ${ }^{18}{ }^{20}{ }^{21}$ and the toe,${ }^{15}$ were also noted. Some patients exhibited haematuria which may have been due to renal emboli, focal embolic glomerulitis or diffuse glomerulonephritis.

Several of the patients had a history of underlying heart disease. Rheumatic fever was a common feature, ${ }^{8112832}$ but patients with ventricular septal defect $^{10}$ and Marfan's syndrome ${ }^{21}$ have also been reported. Four patients had previously received prosthetic heart valves, ${ }^{13} 1618{ }^{23}$ a procedure which is now known to predispose towards the development of bacterial endocarditis. One patient developed

Table 2 Characteristics used to differentiate Neisseria species in the 7th and 8th editions of Bergey's Manual of Determinative Bacteriology ${ }^{4}$

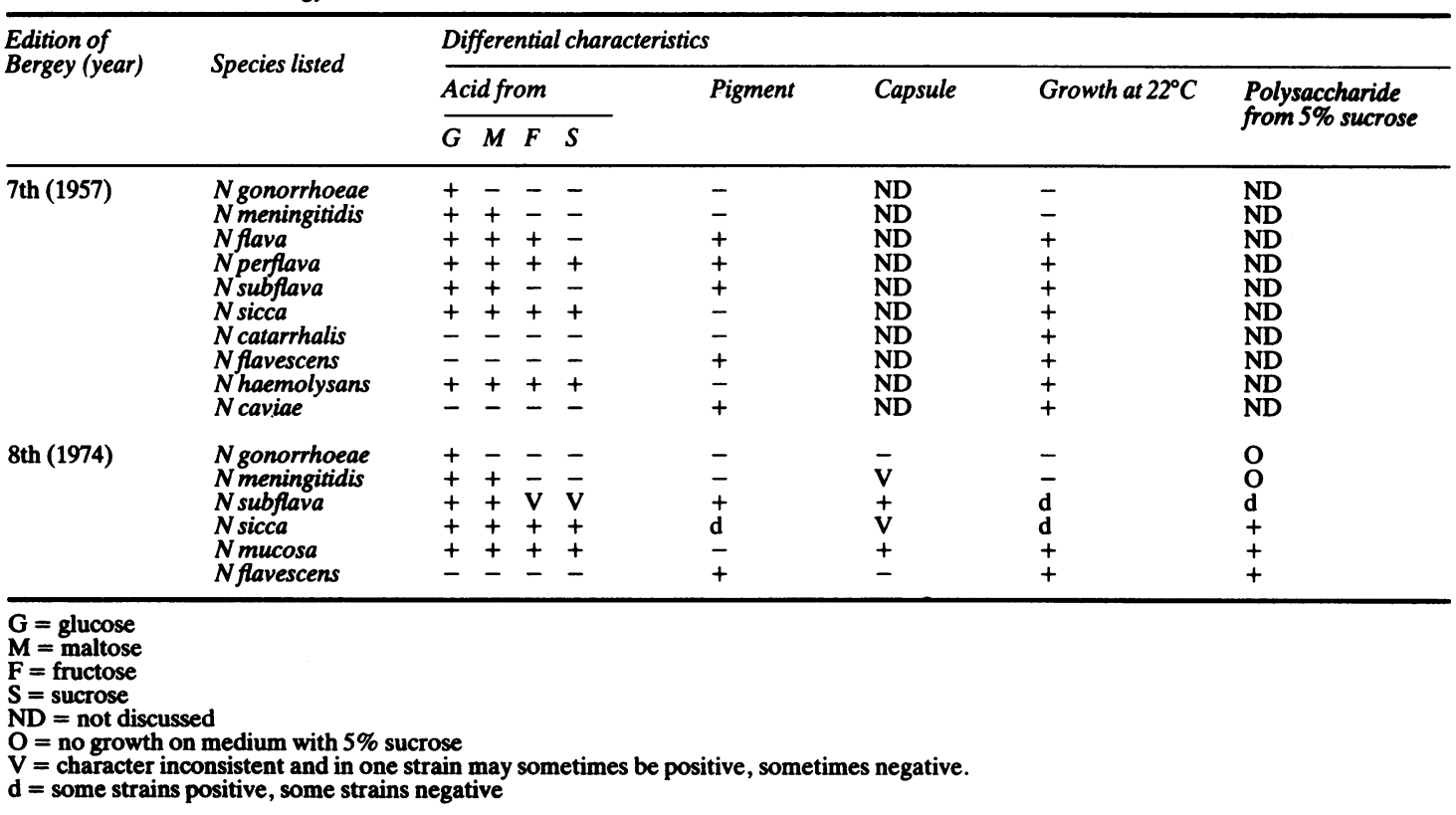


Table 3 Cases of endocarditis caused by Neisseria organisms

\begin{tabular}{|c|c|c|c|c|}
\hline \multirow[t]{2}{*}{ Organism } & \multicolumn{2}{|l|}{ Patient } & \multirow[t]{2}{*}{ Author(s) } & \multirow[t]{2}{*}{ Year published } \\
\hline & Age (yrs) & Sex & & \\
\hline Nflava & $\begin{array}{r}20 \\
14 \\
5\end{array}$ & $\begin{array}{l}\mathbf{F} \\
\mathbf{F}\end{array}$ & $\begin{array}{l}\text { Connaughton and Rountree } \\
\text { Matlage et al }{ }^{8} \\
\text { Scott }^{10}\end{array}$ & $\begin{array}{l}1939 \\
1950 \\
1971\end{array}$ \\
\hline$N$ perflava & $\begin{array}{l}45 \\
44 \\
47\end{array}$ & $\begin{array}{l}\mathbf{M} \\
\mathbf{M} \\
\mathbf{M}\end{array}$ & $\begin{array}{l}\text { Major and Johnson } \\
\text { Breslin } e t a^{12} \\
\text { Clark and Patton } \\
\end{array}$ & $\begin{array}{l}1945 \\
1967 \\
1968\end{array}$ \\
\hline N sicca & $\begin{array}{l}12 \\
60 \\
21\end{array}$ & $\begin{array}{l}\mathbf{M} \\
\mathbf{F} \\
\mathbf{M}\end{array}$ & $\begin{array}{l}\text { Shaw } 14 \\
\text { Gay and Sevier } 15 \\
\text { Ghoneim and Tandon }{ }^{16}\end{array}$ & $\begin{array}{l}1949 \\
1978 \\
1979\end{array}$ \\
\hline$N$ catarrhalis & $\begin{array}{l}15 \\
21 \\
69 \\
45\end{array}$ & $\begin{array}{l}\mathbf{F} \\
\mathbf{M} \\
\mathbf{F} \\
\mathbf{F}\end{array}$ & $\begin{array}{l}\text { Clarke and Haining }{ }^{17} \\
\text { Clarke and Haining }{ }^{17} \\
\text { Pollock and Holzmann }{ }^{18} \\
\text { Douer et a } l^{9}\end{array}$ & $\begin{array}{l}1936 \\
1936 \\
1976 \\
1977\end{array}$ \\
\hline$N$ mucosa & $\begin{array}{r}9 \\
19 \\
54 \\
40\end{array}$ & $\begin{array}{l}\mathbf{M} \\
\mathbf{M} \\
\mathbf{M} \\
\mathbf{M}\end{array}$ & $\begin{array}{l}\text { Brodie et al }{ }^{20} \\
\text { Dowling et al } \\
\text { Drapkin'22 } \\
\text { Hennessey et } a l^{23}\end{array}$ & $\begin{array}{l}1971 \\
1974 \\
1977 \\
1981\end{array}$ \\
\hline Npharyngis & $\begin{array}{l}21 \\
26 \\
21 \\
15\end{array}$ & $\begin{array}{l}\mathbf{F} \\
\mathbf{M} \\
\mathbf{F} \\
\mathbf{M}\end{array}$ & $\begin{array}{l}\text { Goldstein }^{24} \\
\text { Shiling }^{25} \\
\text { Hudson } \\
\text { Linde and Heins }\end{array}$ & $\begin{array}{l}1934 \\
1939 \\
1957 \\
1960\end{array}$ \\
\hline $\begin{array}{l}\text { Micrococcus } \\
\text { pharyngis siccus }\end{array}$ & $\begin{array}{l}27 \\
14\end{array}$ & $\begin{array}{l}\mathbf{M} \\
\mathbf{F}\end{array}$ & $\begin{array}{l}\text { Graef et alps } \\
\text { Weed et al }{ }^{29}\end{array}$ & $\begin{array}{l}1932 \\
1943\end{array}$ \\
\hline $\begin{array}{l}\text { Micrococcus } \\
\text { pharyngitidis-siccae }\end{array}$ & 25 & $\mathbf{M}$ & Schultz ${ }^{30}$ & 1918 \\
\hline Unidentified & $\begin{array}{l}45 \\
25 \\
66\end{array}$ & $\begin{array}{l}\mathbf{M} \\
\mathbf{M} \\
\mathbf{M}\end{array}$ & $\begin{array}{l}\text { Coulter } \\
\text { Shiling } \\
\text { Dammin }^{32}\end{array}$ & $\begin{array}{l}1915 \\
1939 \\
1941\end{array}$ \\
\hline
\end{tabular}

Table 4 Clinical and pathological features of endocarditis caused by Neisseria organisms

\begin{tabular}{|c|c|c|c|}
\hline $\begin{array}{l}\text { Clinical or pathological } \\
\text { feature reported }\end{array}$ & Reference & $\begin{array}{l}\text { Clinical or pathological } \\
\text { feature reported }\end{array}$ & Reference \\
\hline Fever & $\begin{array}{l}8,9,10,11,12,13,15,16,17,18,19,20,21 \\
22,23,24,25,27,28,29,30,31,32\end{array}$ & Abdominal pain & $9,10,13,17,24,25,28$ \\
\hline $\begin{array}{l}\text { Headache } \\
\text { Chills } \\
\text { Vomiting } \\
\text { Muscular aches } \\
\text { Enlargement of heart } \\
\text { Heart murmurs }\end{array}$ & $\begin{array}{l}9,10,12,14,17,20,21,24,29,30 \\
10,11,13,17,19,21,22,23,24,25,29,31,32 \\
8,9,20,28,29,31 \\
8,9,24 \\
8,10,11,17,24,25,28,31,32 \\
8,9,10,11,12,13,15,17,19,20,21,22,25, \\
28,29,30,31,32\end{array}$ & $\begin{array}{l}\text { Splinter haemorrhages } \\
\text { Osler's nodes } \\
\text { Janeway's lesions } \\
\text { Embolic episodes } \\
\text { Clubbing of fingers } \\
\text { History of rheumatic fever }\end{array}$ & $\begin{array}{l}9,11,16,29 \\
16 \\
22 \\
15,16,18,20,21,25,26 \\
14,25 \\
8,11,28,32\end{array}$ \\
\hline $\begin{array}{l}\text { Conjunctival petechiae } \\
\text { Petechiae on skin } \\
\text { Haematuria } \\
\text { Arthralgia/arthritis }\end{array}$ & $\begin{array}{l}8,9,10,11,13,20,28,29,30,32 \\
11,14,16,17,24,28,30,32 \\
8,10,13,15,18,19,21,22,25,28,29,30,32 \\
8,9,15,22,24,31\end{array}$ & $\begin{array}{l}\text { Pre-existing heart valve abnormality } \\
\text { Intracardiac prosthesis } \\
\text { Recent history of dental procedure } \\
\text { Patient died }\end{array}$ & $\begin{array}{l}10,14,21 \\
13,16,18,23 \\
8,18,21,26 \\
8,17,18,24,25,28,30,31,32\end{array}$ \\
\hline
\end{tabular}

early onset endocarditis ${ }^{13}$ - that is, onset within two months of valve replacement-while the other three patients ${ }^{16}{ }^{18}{ }^{23}$ developed late onset disease.

Although the portal of entry for the initiating episode of bacteraemia which resulted in infection of the endocardium was often not apparent, it was thought that the oropharynx was the source of infection in a number of instances. In four patients, endocarditis developed after dental extractions, ${ }^{818} 2126$ and in one patient, bacteraemia was believed to have occurred following the use of an oral irrigation device. ${ }^{22}$ In at least two other patients poor oral hygiene was noted. ${ }^{10}{ }^{32}$ It was suggested that in one patient the source of bacteraemia may have been a genital tract infection, ${ }^{9}$ while in another patient the development of endocarditis was thought to be possibly related to a prior gynaecological operation. ${ }^{19}$

In addition to endocarditis, one case of purulent pericarditis due to a Neisseria organism ( $N$ mucosa) has been described. ${ }^{33} \mathrm{~A}$ 51-year-old man with chronic renal failure developed purulent pericarditis and $N$ mucosa was isolated from pericardial tissue and fluid.

MENINGITIS

Documented cases of meningitis produced by 
Table 5 Cases of meningitis caused by Neisseria organisms

\begin{tabular}{|c|c|c|c|c|}
\hline \multirow[t]{2}{*}{ Organism } & \multicolumn{2}{|l|}{ Patient } & \multirow[t]{2}{*}{ Author(s) } & \multirow[t]{2}{*}{ Year published } \\
\hline & $A g e^{*}$ & Sex & & \\
\hline N flava & 8 days & $\mathbf{M}$ & Noguchi et $a l^{\beta 4}$ & 1963 \\
\hline$N$ perflava & 31 & $\mathbf{M}$ & Sophian ${ }^{35}$ & 1944 \\
\hline Nsubflava & $\begin{array}{l}7 \text { months } \\
7 \text { months } \\
2 \frac{1}{2} \\
9 \text { months }\end{array}$ & $\begin{array}{l}\mathrm{M} \\
\mathrm{F} \\
\mathrm{F} \\
\mathrm{F}\end{array}$ & $\begin{array}{l}\text { Benson et a }{ }^{36} \\
\text { Lewin and Hughes }{ }^{37} \\
\text { Lewin and Hughes } \\
\text { Lewin and Hughes }^{37}\end{array}$ & $\begin{array}{l}1928 \\
1966 \\
1966 \\
1966\end{array}$ \\
\hline$N$ sicca & $6 \frac{1}{2}$ & $\mathbf{M}$ & Bansmer and Brem ${ }^{38}$ & 1948 \\
\hline \multicolumn{5}{|l|}{ Organism resembling } \\
\hline$N$ catarrhalis & 45 & $\mathbf{F}$ & Newing and Christie ${ }^{39}$ & 1947 \\
\hline N catarrhalis & $\begin{array}{l}2 \frac{1}{2} \\
14 \text { months } \\
36 \\
3\end{array}$ & $\begin{array}{l}\mathbf{M} \\
\mathbf{F} \\
\mathbf{M} \\
\mathbf{M}\end{array}$ & $\begin{array}{l}\text { Pfister et al }{ }^{40} \\
\text { Cocchi and Ulivelli }{ }^{41} \\
\text { Elston } \text { et }^{4 l^{42}} \\
\text { Arora and Chitkara }{ }^{43}\end{array}$ & $\begin{array}{l}1965 \\
1968 \\
1970 \\
1973\end{array}$ \\
\hline Micrococcus catarrhalis & $\begin{array}{l}3 \text { months } \\
5 \\
31\end{array}$ & $\begin{array}{l}\overline{\mathbf{F}} \\
\mathbf{F}\end{array}$ & $\begin{array}{l}\text { Wilson } \\
\text { Garland }^{45} \\
\text { Moersch }^{46}\end{array}$ & $\begin{array}{l}1908 \\
1923 \\
1928\end{array}$ \\
\hline$N$ mucosa & 5 & $\mathbf{F}$ & Berger et $a l^{47}$ & 1974 \\
\hline Diplococcus mucosus & $\begin{array}{l}- \\
29 \\
3 \text { months }\end{array}$ & $\begin{array}{l}\overline{\mathbf{M}} \\
\mathbf{F}\end{array}$ & $\begin{array}{l}\text { Cowan }{ }^{48} \\
\text { Bray and Cruickshank } \\
\text { Bishop and Randell }^{50}\end{array}$ & $\begin{array}{l}1938 \\
1943 \\
1947\end{array}$ \\
\hline N lactamica & $\begin{array}{l}7 \text { months } \\
6\end{array}$ & $\begin{array}{l}\mathbf{F} \\
\mathbf{M}\end{array}$ & $\begin{array}{l}\text { Lauer and Fisher } \\
\text { Hansman }\end{array}$ & $\begin{array}{l}1976 \\
1978\end{array}$ \\
\hline N flavescens & $\overline{10}$ & $\overline{\mathbf{M}}$ & $\begin{array}{l}\text { Branham } \\
\text { Prentice }^{53}\end{array}$ & $\begin{array}{l}1930 \\
1957\end{array}$ \\
\hline Unidentified & $\begin{array}{l}7 \\
31 \\
25 \\
4\end{array}$ & $\begin{array}{l}\mathbf{F} \\
\mathbf{M} \\
\mathbf{F} \\
\mathbf{M}\end{array}$ & $\begin{array}{l}\text { Reimann and Koucky } \\
\text { Edwards } \\
\text { Christie and } \text { Cook }^{57} \\
\text { Kippax et al } \\
\text { S8 }\end{array}$ & $\begin{array}{l}1939 \\
1944 \\
1947 \\
1968\end{array}$ \\
\hline
\end{tabular}

*Age in years unless stated otherwise.

Table 6 Cases of meningitis caused by Neisseria organisms reported in languages other than English

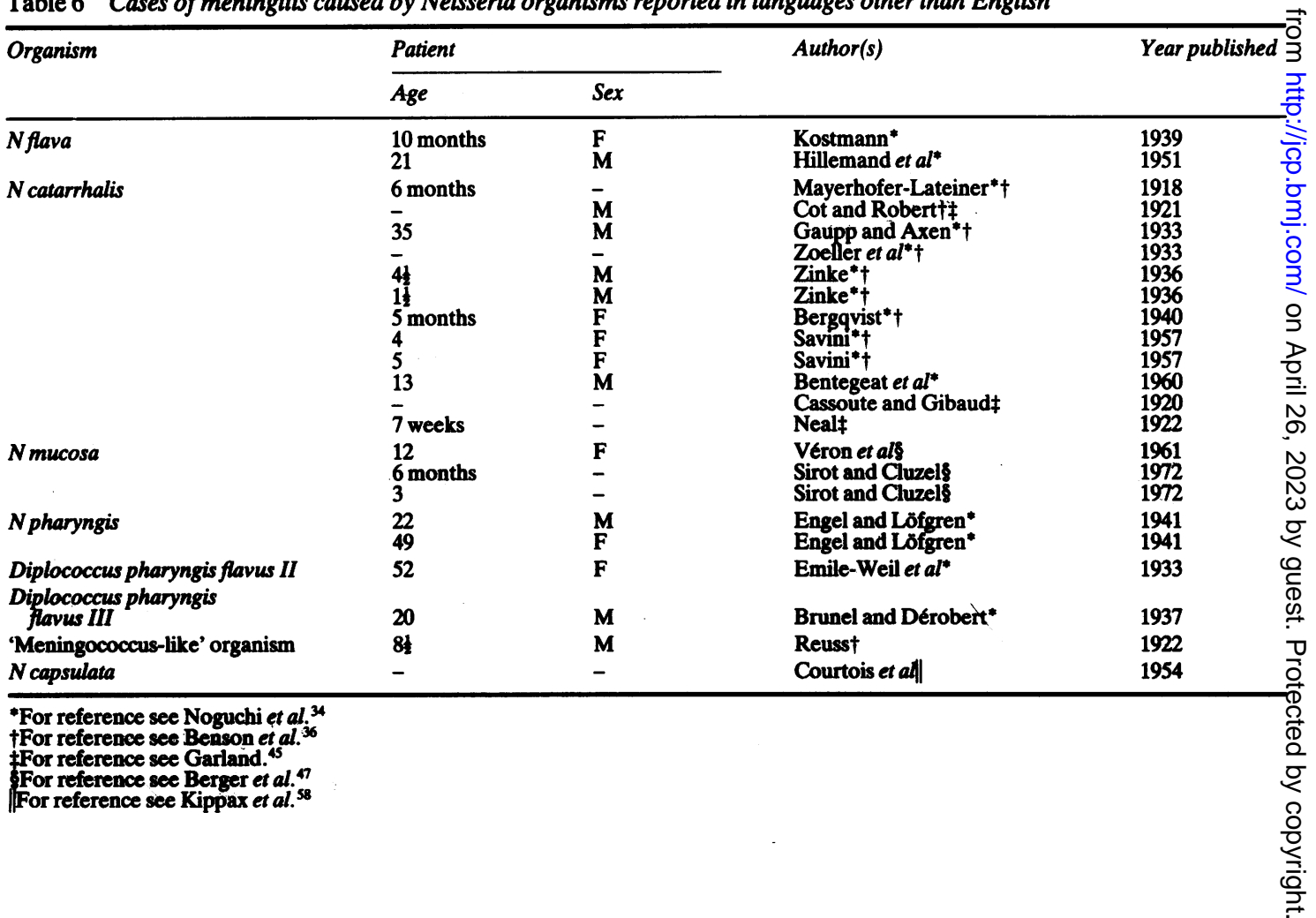


Table 7 Clinical and pathological features of meningitis caused by Neisseria organisms

\begin{tabular}{|c|c|c|c|}
\hline $\begin{array}{l}\text { Clinical or pathological } \\
\text { feature reported }\end{array}$ & Reference & $\begin{array}{l}\text { Clinical or pathological } \\
\text { feature reported }\end{array}$ & Reference \\
\hline Fever & $\begin{array}{l}35,36,37,38,40,41,42,43,44,45,46,47,49,50, \\
51,54,57,58\end{array}$ & $\begin{array}{l}\text { Maculo-papular or purpuric rash } \\
\text { on skin }\end{array}$ & $49,52,57$ \\
\hline Headache & $38,45,46,49,55,57$ & Neck stiffness & \multirow{3}{*}{$\begin{array}{l}35,38,40,41,42,45,47,49, \\
52,54,55,58 \\
35,36,38,40,41,45,54,55 \\
57,58 \\
35,47 \\
35,36,40,41,47\end{array}$} \\
\hline Vomiting & $36,37,38,39,41,44,45,46,47,54,55,58$ & Positive Kernig's sign & \\
\hline $\begin{array}{l}\text { Lethargy/drowsiness } \\
\text { Altered state or loss } \\
\text { of consciousness }\end{array}$ & $\begin{array}{l}37,38,39,40,43,45,47,51,52,57,58 \\
37,39,40,42,43,57\end{array}$ & $\begin{array}{l}\text { Positive Babinski's sign } \\
\text { Positive Brudzinski's sign }\end{array}$ & \\
\hline $\begin{array}{l}\text { Confusion } \\
\text { Convulsions } \\
\text { Bulging fontanelle }\end{array}$ & $\begin{array}{l}35,39,49,57 \\
37,40,43,44,58 \\
36,44,50\end{array}$ & $\begin{array}{l}\text { Positive Oppenheim's sign } \\
\text { Positive Gordon's sign } \\
\text { Cloudy cerebro-spinal fluid }\end{array}$ & \multirow{2}{*}{$\begin{array}{l}35 \\
35 \\
35,36,38,39,40,41,44,45,46, \\
49,50,51,55 \\
35,38,39,45,49,50,57,58\end{array}$} \\
\hline $\begin{array}{l}\text { Inflammation or infection } \\
\text { of upper respiratory tract }\end{array}$ & $36,37,38,39,41,42,45,47,49,51,56,57$ & Cerebral-spinal fluid under & \\
\hline Petechiae on skin & $35,37,40,41,44,47,49$ & Patient died & $35,36,37,39,44,45,46,56,57$ \\
\hline
\end{tabular}

Table 8 Pathological findings in cerebro-spinal fluid from patients with meningitis caused by Neisseria organisms

\begin{tabular}{|c|c|c|c|c|c|c|}
\hline \multirow[t]{2}{*}{ Organism } & \multicolumn{4}{|c|}{ Findings in cerebrospinal fluid } & \multirow[b]{2}{*}{ Author(s) } & \multirow[b]{2}{*}{ Year published } \\
\hline & $\begin{array}{l}\text { No of } \\
\text { inflammatory cells } \\
\text { (cells/litre) }\end{array}$ & $\begin{array}{l}\text { Glucose } \\
\text { (mmolli) }\end{array}$ & $\begin{array}{l}\text { Protein } \\
\left(g^{\prime} / l\right)\end{array}$ & $\begin{array}{l}\text { Gram-negative } \\
\text { diplococci seen } \\
\text { in smear }\end{array}$ & & \\
\hline $\begin{array}{l}\text { N perflava } \\
N \text { subflava } \\
\text { N sicca } \\
N \text { catarrhalis }\end{array}$ & $\begin{array}{l}1.5 \times 10^{10} \\
4.8 \times 10^{9} \\
1.9 \times 10^{9} \\
4.0 \times 10^{6} \\
4.2 \times 10^{9} \\
3.0 \times 10^{9} \\
1.2 \times 10^{9} \\
7.6 \times 10^{9} \\
10-12 \mathrm{HPF}\end{array}$ & $\begin{array}{l}\text { NR } \\
0 \cdot 17 \\
0 \cdot 22 \\
1.7 \\
4 \cdot 6 \\
\text { NR } \\
1 \cdot 7 \\
2 \cdot 1 \\
1.4\end{array}$ & $\begin{array}{l}\text { NR } \\
1.9 \\
1.4 \\
0.4 \\
0.8 \\
\text { NR } \\
0.7 \\
3.5 \\
0.7\end{array}$ & $\begin{array}{l}+ \\
+ \\
+ \\
+ \\
+ \\
+ \\
+ \\
+\end{array}$ & $\begin{array}{l}\text { Sophian } \\
\text { Lewin and Hughes }^{37} \\
\text { Lewin and Hughes }^{37} \\
\text { Lewin and Hughes }^{37} \\
\text { Bansmer and Brem } \\
\text { Pfister et al } \\
\text { Cocchi and Ulivelli41 } \\
\text { Elston et al }{ }^{42} \\
\text { Arora and Chitkara }{ }^{43}\end{array}$ & $\begin{array}{l}1944 \\
1966 \\
1966 \\
1966 \\
1948 \\
1965 \\
1968 \\
1970 \\
1973\end{array}$ \\
\hline $\begin{array}{l}M \text { catarrhalis } \\
N \text { mucosa } \\
\text { (D mucosus) }\end{array}$ & $\begin{array}{l}1.5 \times 10^{9} \\
2.3 \times 10^{9} \\
3.3 \times 10^{8} \\
2.0 \times 10^{8}\end{array}$ & $\begin{array}{l}1.9 \\
\text { Normal } \\
\text { NR } \\
1.9\end{array}$ & $\begin{array}{l}\text { increased } \\
\text { Normal } \\
2.4 \\
1.9\end{array}$ & $\begin{array}{l}+ \\
+ \\
+\end{array}$ & $\begin{array}{l}\text { Garland } \\
\text { Berger } e t a l^{47} \\
\text { Bray and Cruickshank } \\
\text { Bishon and Randall }\end{array}$ & $\begin{array}{l}1923 \\
1974 \\
1943 \\
1947\end{array}$ \\
\hline $\begin{array}{l}\text { N lactamica } \\
\text { N flavescens } \\
\text { Undescribed }\end{array}$ & $\begin{array}{l}1.3 \times 10^{10} \\
2.6 \times 10^{7} \\
2.9 \times 10^{8} \\
1.1 \times 10^{8}\end{array}$ & $\begin{array}{l}\text { Not detected } \\
4 \cdot 4 \\
\text { Not detected } \\
4 \cdot 3\end{array}$ & $\begin{array}{l}2.5 \\
0.5 \\
2 \cdot 0 \\
0.3\end{array}$ & $\begin{array}{l}\dot{+} \\
+ \\
+ \\
\text { NR }\end{array}$ & $\begin{array}{l}\text { Lauer and Fisher } \\
\text { Prentice } \\
\text { Christie and Cook } \\
\text { Kippax et al } \text { I }^{88}\end{array}$ & $\begin{array}{l}1976 \\
1957 \\
1947 \\
1968\end{array}$ \\
\hline
\end{tabular}

HPF $=$ high power field.

$\mathrm{NR}=$ not reported.

Neisseria spp other than the gonococcus and the meningococcus are listed in Tables 5 and 6. Most patients presented with meningeal symptoms such as headache, vomiting, lethargy, neck stiffness, and positive Kernig's and Brudzinski's signs (Table 7) which are common to many types of meningitis. Interestingly, several patients had a petechial, maculo-papular or purpuric rash (Table 7) which is a feature commonly associated with cases of meningococcal meningitis. Gram-negative cocci were frequently seen in smears of cerebrospinal fluid (CSF) (Table 8) and in all cases the diagnosis was confirmed by isolation of the organisms from the CSF and occasionally from the blood.

The findings in the CSF were generally consistent with those seen in other forms of bacterial meningitis
(Table 8). The white blood cell count was commonly, though not invariably, greatly than $1.2 \times 10^{9} / 1$ with a predominance of polymorphonuclear leucocytes. In the cases where glucose and protein concentrations in CSF were recorded, about half the patients had glucose concentrations $\leqslant 1.7 \mathrm{mmol} / /$, and about half had protein concentrations $>1.5 \mathrm{~g} /$.

\section{SEPTICAEMIA}

The clinical and microbiological features of documented cases of Neisseria septicaemia are shown in Table 9. It must be remembered, however, that invasion of the blood stream by bacteria occurs also in cases of endocarditis and meningitis (see above), and that there is an overlap with regard to the clinical features of these conditions. In all the reported cases 
Table 9 Clinical and pathological features of septicaemia caused by Neisseria organisms

\begin{tabular}{|c|c|c|c|c|c|c|}
\hline \multirow[t]{2}{*}{ Organism } & \multicolumn{2}{|l|}{ Patient } & \multirow{2}{*}{ Clinical features } & \multirow[t]{2}{*}{ Bacteriological features } & \multirow[t]{2}{*}{ Author(s) } & \multirow{2}{*}{$\begin{array}{l}\text { Year } \\
\text { published }\end{array}$} \\
\hline & $A g e^{*}$ & Sex & & & & \\
\hline N subflava & 3 months & $\mathbf{M}$ & $\begin{array}{l}\text { History of coryza and cough } 1 \text { wk prior to } \\
\text { admission, fever, loss of consciousness, } \\
\text { generalised petechial rash, pupils unresponsive to } \\
\text { light, deep tendon reflexes absent, right upper } \\
\text { lobe pneumonia, patient died. }\end{array}$ & Bacteria isolated from blood & $\begin{array}{l}\text { Lewin and } \\
\text { Hughes }^{37}\end{array}$ & 1966 \\
\hline N subflava & 2 & $\mathbf{F}$ & $\begin{array}{l}\text { History of coryza and cough } 1 \text { wk prior to } \\
\text { admission, fever, generalised petechial rash, } \\
\text { tonsillar fauces inflamed, haematuria, patient } \\
\text { recovered. }\end{array}$ & Bacteria isolated from blood & $\begin{array}{l}\text { Lewin and } \\
\text { Hughes }^{37}\end{array}$ & 1966 \\
\hline N subflava & 10 & $\mathbf{M}$ & $\begin{array}{l}\text { Fever, nausea, stomach ache, mild pharyngitis, } \\
\text { macular-purpuric skin rash, patient recovered. }\end{array}$ & Bacteria isolated from blood & $\begin{array}{l}\text { Muchmore and } \\
\text { Venters }\end{array}$ & 1968 \\
\hline$N$ catarrhalis & 6 months & $\mathbf{M}$ & $\begin{array}{l}\text { History of fever and vomiting } 2 \text { days before } \\
\text { admission, sudden onset of purpuric lesions, few } \\
\text { spontaneous movements, pupils sluggish to light, } \\
\text { CSF clear and colourless, patient recovered. }\end{array}$ & $\begin{array}{l}\text { Bacteria isolated from blood, } \\
\text { CSF and bone marrow }\end{array}$ & Feigin et al ${ }^{60}$ & 1969 \\
\hline$N$ catarrhalis & 8 & $\mathbf{M}$ & $\begin{array}{l}\text { History of immunosuppressive therapy for acute } \\
\text { lymphoblastic leukaemia, fever, malaise, nausea, } \\
\text { abdominal distension, purpuric rash, pain and } \\
\text { swelling in both knees, extensive oropharyngeal } \\
\text { ulceration, patient died. }\end{array}$ & $\begin{array}{l}\text { Bacteria isolated from blood. } \\
\text { Bacteria seen in Gram-stain } \\
\text { of material obtained by } \\
\text { needling from cutaneous } \\
\text { lesions }\end{array}$ & Burnett et al ${ }^{61}$ & 1975 \\
\hline Npharyngis & 24 & $\mathbf{F}$ & $\begin{array}{l}\text { Patient collapsed at work. } \\
\text { Evidence of disseminated intravascular } \\
\text { coagulation. Patient died. }\end{array}$ & $\begin{array}{l}\text { Bacteria isolated from blood } \\
\text { and from heart swab taken at } \\
\text { autopsy }\end{array}$ & $\begin{array}{l}\text { Thomson and } \\
\text { Gopaul }^{62}\end{array}$ & 1973 \\
\hline N lactamica & 23 months & $\mathbf{F}$ & $\begin{array}{l}\text { Patient had chromosomal defect and suffered } \\
\text { from patent ductus arteriosus with pulmonary } \\
\text { hypertension. } \\
\text { Patient found lifeless in bed but resuscitated. } \\
\text { On admission, patient had inflamed and dull } \\
\text { right tympanic membrane. }\end{array}$ & $\begin{array}{l}\text { Bacteria isolated from blood. } \\
\text { Bacteria seen in Gram-stain } \\
\text { of fluid from middle ear. }\end{array}$ & $\begin{array}{l}\text { Wilson and } \\
\text { Overman }^{63}\end{array}$ & 1976 \\
\hline Nflavescens & 20 & $\mathbf{F}$ & $\begin{array}{l}\text { Fever, chills, headache, vomiting, myalgia, } \\
\text { arthralgia, maculopapular and pustular skin } \\
\text { lesions, third right metacarpophalangeal } \\
\text { joint inflamed, CSF clear, patient recovered. }\end{array}$ & $\begin{array}{l}\text { Bacteria isolated from blood. } \\
\text { Bacteria seen in Gram-stain } \\
\text { of pustular skin lesion, but } \\
\text { cultures were negative. }\end{array}$ & $\begin{array}{l}\text { Wertlake and } \\
\text { Williams }\end{array}$ & 1968 \\
\hline
\end{tabular}

*Age in years unless otherwise stated.

of Neisseria septicaemia organisms were isolated from the blood, but additionally in one case, organisms were isolated from the CSF and bone marrow, ${ }^{60}$ while in two other cases organisms were seen in Gram-stained materials from skin lesions. ${ }^{61} 64$ The cases described here are of particular interest in that they resemble the clinical picture generally seen in meningococcal septicaemia, with the development of a maculo-papular, petechial or purpuric rash. Other similarities include fever, ${ }^{37} 59606164$ joint involvement, ${ }^{6164}$ and, in one patient, evidence of disseminated intravascular coagulation. ${ }^{62}$

In some of the patients, septicaemia may have followed an upper respiratory tract infection. Three patients had a history of either coryza and cough ${ }^{37} 60$ (although relevant microbiological data were not available) or pharyngitis, ${ }^{59}$ and in one patient, organisms were detected microscopically in fluid from the middle ear. ${ }^{63}$ One other patient was predisposed to infection as a result of receiving immunosuppressive drugs. ${ }^{61}$

RESPIRATORY TRACT INFECTIONS

Although Koch's postulates have not been fulfilled, the isolation of Neisseria organisms in pure culture from the heart, CSF or blood (organs and tissues 3 which are normally sterile) provides strong cir-? cumstantial evidence that these organisms are the? aetiological agents in the cases of endocarditis, meningitis and septicaemia described above. With: regard to respiratory tract infections, however, the 3 . interpretation of bacteriological findings is more difficult as Neisseria organisms are known to exist as harmless inhabitants of the upper respiratory tract.o With this proviso in mind, there is, nevertheless, an? accumulating body of evidence which suggests thato one particularspecies-namely $N$ catarrhalis (recently

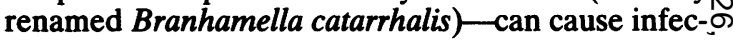
tions in both the upper and lower respiratory tract N (Table 10). There is only serological evidence to support an aetiological role for $N$ catarrhalis in some ${ }_{O}^{\omega}$ cases of sinusitis, ${ }^{65}$ but the evidence for it causing otitis media in children is stronger, the organisms having been isolated in pure culture from middle ear@ exudates and having been seen associated with polymorphonuclear leucocytes in Gram-stained ${ }_{0}^{-}$ smears. ${ }^{66-70}$ Moreover, it is unlikely that these isolates were simply contaminants from the oropharynx, $\frac{O}{\mathbb{Q}}$ since other organisms also found normally in the $\frac{\varrho}{\sigma}$ oropharynx were not isolated. In a study of acute 
Table 10 Evidence for aetiological role of Neisseria catarrhalis (Branhamella catarrhalis) in respiratory tract infections

\begin{tabular}{|c|c|c|c|c|}
\hline Infection & $\begin{array}{l}\text { Evidence for aetiological role of } \\
\text { N catarrhalis (Branhamella catarrhalis) }\end{array}$ & $\begin{array}{l}\text { Predisposing host } \\
\text { factor }\end{array}$ & Author(s) & $\begin{array}{l}\text { Year } \\
\text { published }\end{array}$ \\
\hline $\begin{array}{l}\text { Maxillary } \\
\text { sinusitis }\end{array}$ & $\begin{array}{l}\text { Complement-fixing antibodies present in sera of } \\
\text { some patients. }\end{array}$ & ND & Brorson et als5 & 1976 \\
\hline Otitis media & $\begin{array}{l}\text { Organisms isolated in pure culture from middle ear } \\
\text { exudate; Organisms seen in association with PMN } \\
\text { leucocytes in middle ear exudate; antibodies detected } \\
\text { in serum and/or middle ear fluid of patients from } \\
\text { whom organisms were isolated. }\end{array}$ & ND & 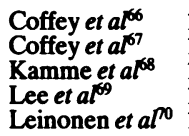 & $\begin{array}{l}1966 \\
1967 \\
1971 \\
1981 \\
1981\end{array}$ \\
\hline Laryngitis & $\begin{array}{l}\text { Organisms isolated as sole pathogen from nasopharynx } \\
\text { in } 55 \% \text { of patients studied. }\end{array}$ & None & Schalén et $a l^{1}$ & 1980 \\
\hline $\begin{array}{l}\text { Bronchitis or } \\
\text { pneumonia }\end{array}$ & Predominant organisms in sputum. & $\begin{array}{l}\text { All patients had chronic } \\
\text { underlying lung disease. }\end{array}$ & Johnson et al ${ }^{2}$ & 1981 \\
\hline \multirow[t]{3}{*}{ Pneumonia } & \multirow{3}{*}{$\begin{array}{l}\text { Organisms isolated in pure culture from sputum and } \\
\text { transtracheal aspirate; organisms seen associated with } \\
\text { PMN leucocytes in Gram-stained sputum and } \\
\text { transtracheal aspirate; positive correlation between } \\
\text { disappearance of organisms and clinical improvement. }\end{array}$} & $\begin{array}{l}\text { Patient received immunosuppressive } \\
\text { therapy for multiple myoloma. }\end{array}$ & McNeely et $a l^{33}$ & 1976 \\
\hline & & $\begin{array}{l}\text { One patient had chronic lymphocytic } \\
\text { leukaemia and another was an } \\
\text { alcoholic with chronic obstructive } \\
\text { pulmonary disease. }\end{array}$ & \multicolumn{2}{|c|}{ Srinivasan et a $l^{4} 1981$} \\
\hline & & $\begin{array}{l}\text { Patients were miners with altered } \\
\text { pulmonary function; they all suffered } \\
\text { from repeated respiratory tract } \\
\text { infections and many had received } \\
\text { corticosteroids. }\end{array}$ & $\begin{array}{l}\text { Ninane et a } l^{5} \\
\text { Ninane et al } l^{6} \\
\text { Ninane et al }\end{array}$ & $\begin{array}{l}1977 \\
1978 \\
1978\end{array}$ \\
\hline
\end{tabular}

$\mathrm{ND}=$ not done

laryngitis in non-compromised adults, $B$ catarrhalis was isolated as the sole pathogen in $55 \%$ of the patients, a figure significantly higher than that for the control group. ${ }^{71}$

There is also fairly convincing evidence that $N$ catarrhalis may cause bronchopneumonia, these organisms having been isolated in pure culture from bronchial secretions obtained by transtracheal puncture ${ }^{72-77}$ which is widely accepted as the procedure of choice for collecting uncontaminated material from the lower respiratory tract. Moreover, in the studies reported by Ninane and colleagues, ${ }^{76}$ transtracheal aspirates containing epidermoid cells were discarded thus reducing the possibility that the aspirates were contaminated with oropharyngeal secretions.

Further evidence for the pathogenic role of $N$ catarrhalis in cases of pneumonia was a correlation between the disappearance of the organisms and the resolution of clinical symptoms. Generally, treatment with ampicillin or other antibiotics resulted in the disappearance of the organisms and clinical improvement. ${ }^{76}$ However, in some patients treated with ampicillin or amoxycillin, the organisms persisted as did signs and symptoms of infection. ${ }^{72} 7576$ Laboratory investigation showed the persistent strains to produce $\beta$-lactamase. ${ }^{27} 7 \pi$ When the patients were treated subsequently with either cefuroxime, ${ }^{75}$ (a cephalosporin active against $\beta$-lactamase-producing organisms), tetracycline ${ }^{72}$ or a combination of amoxycillin and clavulanic-acid ${ }^{77}$ (a $\beta$-lactamase inhibitor) the organisms were eliminated and the condition of the patients improved.
Neisseria catarrhalis (occasionally producing $\beta$-lactamase) was also recorded as a respiratory tract pathogen by Percival and colleagues. ${ }^{78}$ Interestingly, these workers noted that although $N$ catarrhalis was the sole pathogen isolated from some patients, it was more frequently isolated together with Haemophilus influenzae and pneumococci. All the patients from whom $N$ catarrhalis was isolated were chronic bronchitics or had bronchiectasis.

In addition to $N$ catarrhalis, three other Neisseria organisms have been reported as being associated with infections related to the respiratory tract. Neisseria sicca has been isolated in pure culture from the transtracheal aspirate of an elderly patient suffering from pneumonia, ${ }^{79}$ and $N$ mucosa has been isolated from the pleural space of a patient suffering from empyema a year after pneumonectomy. ${ }^{80}$ Neisseria lactamicus was isolated from the pharynx of a man suffering from fever, chills, and pharyngitis, ${ }^{81}$ but the role that the organism played in the disease is questionable since $N$ lactamicus may be isolated from the healthy nasopharynx..$^{82}$

\section{GENITAL TRACT INFECTIONS}

It is frequently thought that the observation of Gramnegative diplococci in genital tract smears is evidence of a gonococcal infection. However, as shown in Table 11, several species of Neisseria other than the gonococcus have been isolated from the genital tract. It should also be mentioned that meningococci have similarly been isolated..$^{90}$

While it is now clear that Neisseria organisms other 
Table 11 Occurrence of Neisseria organisms in the genital tract

\begin{tabular}{|c|c|c|}
\hline Organism & Author(s) & $\begin{array}{l}\text { Year } \\
\text { published }\end{array}$ \\
\hline$N$ flava & $\begin{array}{l}\text { Carpenter } \\
\text { Wax }^{84} \\
\text { Wilkinson }^{85}\end{array}$ & $\begin{array}{l}1943 \\
1950 \\
1952\end{array}$ \\
\hline$N$ subflava & $\begin{array}{l}\text { Johnston } \\
\text { Wax }^{84}\end{array}$ & $\begin{array}{l}1951 \\
1950\end{array}$ \\
\hline N sicca & $\begin{array}{l}\text { Wax }^{84} \\
\text { Weaver }^{87} \\
\text { Wilkinson }^{85}\end{array}$ & $\begin{array}{l}1950 \\
1950 \\
1952\end{array}$ \\
\hline$N$ catarrhalis & $\begin{array}{l}\text { Wax } \\
\text { Wilkinson }^{85} \\
\text { Graber et al a } \\
\text { McCague et al } \\
\text { Blackwell et al }\end{array}$ & $\begin{array}{l}1950 \\
1952 \\
1963 \\
1976 \\
1978\end{array}$ \\
\hline N lactamicus & Jephcott and Morton ${ }^{91}$ & 1972 \\
\hline N lactamica & Brunton et al $l^{2}$ & 1980 \\
\hline$N$ flavescens & $\mathrm{Wax}^{84}$ & 1950 \\
\hline $\begin{array}{l}\text { Aberrant strain of } \\
N \text { catarrhalis or } \\
N \text { gonorrhoeae }\end{array}$ & Coleman ${ }^{93}$ & 1946 \\
\hline
\end{tabular}

than the gonococcus may be isolated from the genital tract, it is not clear whether these organisms cause pathological changes. In some cases it was suggested that the organisms isolated were acting as pathogens, while in other instances the evidence suggested that they were not directly involved in the disease process. However, the results of these studies are difficult to interpret for several reasons. Firstly, the isolation of organisms from patients with no evidence of genital tract disease does not negate the possibility that the organisms may be pathogenic, as the gonococcus (a known genital tract pathogen) frequently produces asymptomatic infections. Secondly and more importantly, some of the patients described in the papers listed in Table 11 may also have been infected with genital pathogens such as Chlamydia trachomatis or Ureaplasma urealyticum which would not have been detected by conventional bacteriology. If non-gonococcal Neisseria species are to be shown to be pathogenic for the genital tract, they must first be isolated from patients from whom no other genital pathogens can be recovered. Until such studies are carried out, the relevance of non-gonococcal Neisseria species to the aetiology of genital tract disease will remain purely speculative.

\section{Factors possibly influencing the development of} infection with Neisseria organisms

From the epidemiological standpoint, most of the reports of non-gonococcal non-meningococcal Neisseria infection take the form of case histories rather than reports of outbreaks (although one mild epidemic of meningitis due to $N$ flavescens was reported 50 years ago $^{53}$ ) suggesting minimal person to person transmission. As Neisseria organisms other than the gonococcus or meningococcus normally exist as inhabitants of the oropharynx, development of disease is probably due in most instances, to endogenous spread of infection and probably reflects either reduced resistance to infection on the part of the host or enhanced virulence of the infecting strain. In some of the reported cases it was evident that the patients were prone to infection as a result of immunosuppressive therapy or because of chronic lung disease, but in the majority of cases the underlying cause of disease was not known. In view of our current lack of knowledge concerning the pathogenesis of these infections it must be stressed that much of what follows is speculative.

The first stage in the development of diseases such as endocarditis, meningitis or septicaemia must involve the haematogenous spread of organisms from the oropharynx. Micro-organisms in the oropharynx enter the blood stream following oral trauma, which may be severe-for example dental extraction-or relativelymild-for example tooth brushing, chewing. Micro-organisms that enter the blood stream are usually eliminated within a short time, but the isolation of Neisseria organisms from blood in cases of endocarditis, meningitis or septicaemia suggests that they may be resistant to the bactericidal activity of human serum. Strains of gonococci vary in their susceptibility to killing by serum when cultured in vitro, with strains associated with disseminated infection being generally more serum-resistant than strains isolated from cases of localised infection. ${ }^{94}$ It would clearly be of interest to see if other species of Neisseria isolated from blood were similarly serumresistant in comparison with commensal strains of the same species which appear to be serum-susceptible. ${ }^{95}$ An alternative explanation for the ability of Neisseria organisms to survive in the blood stream is that the patient's serum may be defective in killing microorganisms. It is now known that deficiency of terminal components of the complement system predisposes to repeated systemic infection with $N$ gonorrhoeae and $N$ meningitidis. ${ }^{96}$ It would be of value to know if such complement deficiencies are present in the sera of patients infected with other Neisseria species.

After invading the blood stream, the microorganisms must be capable of colonising appropriate anatomical sites such as the heart or nervous system if $\stackrel{\mathscr{S}}{?}$ they are to produce infection. If they are to colonise the heart effectively, for example, they must be capable of attaching to valve leaflets or other areas of the endocardium. Gould et al $l^{p 7}$ reported that species of bacteria commonly associated with bacterial endocarditis adhered in significantly higher numbers 
to the endothelial surfaces of human and canine aortic valve leaflets in vitro, than did bacteria not associated with this disease. In view of these findings, it would be of interest to determine if Neisseria organisms isolated from cases of endocarditis adhered to heart tissue more readily than organisms isolated from the healthy oropharynx. Attachment would also be an important prerequisite for the successful colonisation of the genital tract, either as the first step in the process of infection, or simply in the establishment of a commensal genital tract flora.

Once established at a potential site of infection, Neisseria organisms must be capable of resisting host defences. As with gonococcal and meningococcal infections, the host appears to respond to an opportunistic Neisseria infection with an acute inflammatory reaction. The persistence of Neisseria organisms in the presence of large numbers of polymorphonuclear leucocytes implies either that the bacteria are capable of resisting to some extent the bactericidal activity of these phagocytic cells, or that the polymorphonuclear leucocytes from patients with opportunistic Neisseria infections are defective at killing these organisms. This question could be resolved perhaps by performing in vitro phagocytosis studies with polymorphonuclear leucocytes from patients and from healthy donors, and by using Neisseria organisms of apparently differing virulence. Such studies have been reported previously for $\mathrm{N}$ gonorrhoeae. ${ }^{98}$

\section{Conclusions}

The great interest shown by researchers during the last few decades in the study of gonoccoci and meningococci has resulted in a steady increase in our knowledge and understanding of the diseases produced by these organisms. By way of contrast relatively little attention has been paid to the other Neisseria species, as they have generally been regarded as harmless organisms of little clinical importance. While it is true to say that the latter bacteria do not rank among the major pathogens encountered in the field of infectious diseases, it would appear that they may cause infections more frequently than is commonly appreciated, and microbiologists should guard against dismissing too readily as normal flora, Neisseria species isolated from clinical material.

Addendum After this paper was submitted for publication, a report appeared in the literature describing a case of osteomyelitis due to $N$ sicca. Reference

Doern GV, Blacklow NR, Gantz NM, Avcoin P, Fischer RA,
Parker DS. Neisseria sicca osteomyelitis. J Clin Microbiol 1982; 16:595-9.

\section{References}

${ }^{1}$ Brooks GF, Gotschlich EC, Holmes KK, Sawyer WD, Young FE, eds. Immunobiology of Neisseria gonorrhoeae. Washington DC: American Society for Microbiology, 1978.

${ }^{2}$ Danielsson D, Normark S, eds. Genetics and immunobiology of pathogenic Neisseria. Umea, Sweden 1980: University of Umea Press.

${ }^{3}$ Wilson GS, Smith MM. Observations on Gram-negative cocci of the nasopharynx, with description of Neisseria pharyngis. $J$ Pathol Bacteriol 1928;31:597-608.

${ }^{4}$ Branham SE, Pelczar MJ, Family VIII. Neisseriaceae Prévot, 1933. Genus I. Neisseria Trevisan 1885. In: Breed RS, Murray EGD, Smith NR, eds. Bergey's manual of determinative bacteriology 7th ed. Baltimore: The Williams and Wilkins Co, 1957: 480-5.

${ }^{5}$ Kingsbury DT. Deoxyribonucleic acid homologies among species of the genus Neisseria. J Bacteriol 1967;94:870-4.

${ }^{6}$ Henriksen SD, Bøvre K. The taxonomy of the genera Moraxella and Neisseria. J Gen Microbiol 1968;51:387-92.

${ }^{7}$ Reyn A, Family I. Neisseriaceae Prévot 1933. Genus I. Neisseria Trevisan 1885. In: Buchanan RE, Gibbons NE, eds. Bergey's manual of determinative bacteriology, 8th ed. Baltimore: The Williams and Wilkins Co, 1974; 427-32.

${ }^{8}$ Connaughton FW, Rountree PM. A fatal case of infective endocarditis due to Neisseria flava. Med J Aust 1939;2:138-9.

${ }^{9}$ Matlage WT, Harrison PE, Greene JA. Neisseria flava endocarditis: With report of a case. Ann Intern Med 1950:33:1494-8.

${ }^{10}$ Scott RM. Bacterial endocarditis due to Neisseria flava. J Pediatr 1971;78:673-5.

${ }^{11}$ Major RH, Johnson EW. Neisseria perflava endocarditis; Recovery. JAMA 1945;127:1051-2.

${ }^{12}$ Breslin AB, Biggs JC, Hall GV. Bacterial endocarditis due to Neisseria perflava in a patient hypersensitive to penicillin. Aust Ann Med 1967;16:245-9.

${ }^{13}$ Clark H, Patton RD. Postcardiotomy endocarditis due to Neisseria perflava on a prosthetic aortic valve. Ann Intern Med 1968;68:386-9.

${ }^{14}$ Shaw FW. The pathogenicity of Neisseria sicca. Science 1949;75:488.

${ }^{15}$ Gay RM, Sevier RE. Neisseria sicca endocarditis: report of a case and review of the literature. J Clin Microbiol 1978;8:729-32.

${ }^{16}$ Ghoneim ATM, Tandon AP. Prosthetic valve endocarditis due to Neisseria sicca: a case report. Indian Heart J 1979;31:246-8.

${ }^{17}$ Clarke RM, Haining RB. Neisseria catarrhalis endocarditis. Ann Intern Med 1936-37;10:117-21.

${ }^{18}$ Pollock AA, Holzman RS. Neisseria catarrhalis endocarditis. Ann Intern Med 1976;85:206-7.

${ }^{19}$ Douer D, Danziger Y, Pinkhas J. Neisseria catarrhalis endocarditis. Ann Intern Med 1977;86:116.

${ }^{20}$ Brodie E, Adler JL, Daly AK. Bacterial endocarditis due to an unusual species of encapsulated Neisseria: Neisseria mucosa endocarditis. Am J Dis Child 1971;122:433-7.

${ }^{21}$ Dowling JN, Lee W-S, Sacco RJ, Ho M. Endocarditis caused by Neisseria mucosa in Marfan's syndrome. Ann Intern Med 1974;81:641-3.

22 Drapkin MS. Endocarditis after the use of an oral irrigation device. Ann Intern Med 1977;87:455.

${ }^{23}$ Hennessey R, Reinhart JH, McGuckin MB. Endocarditis caused by Neisseria mucosa in a patient with a prosthetic heart valve. Am J Med Technol 1981;47:909-11.

${ }^{24}$ Goldstein JD, Endocarditis due to a Neisseria pharyngis organism. Am J Med Sci 1934;187:672-7.

${ }^{25}$ Shiling MS. Bacteriology of endocarditis with report of two unusual cases. Ann Intern Med 1939;13:476-86. 
${ }^{26}$ Hudson R. Neisseria pharyngis bacteriaemia in a patient with subacute bacterial endocarditis. J Clin Pathol 1957;10:195-6.

${ }^{27}$ Linde LM, Heins HL. Bacterial endocarditis following surgery for congenital heart disease. N Engl J Med 1960;263:65-9.

${ }^{28}$ Graef I, De La Chapelle CE, Vance MC. Micrococcus pharyngis siccus endocarditis. Am J Pathol 1932;8:347-54.

${ }^{29}$ Weed MR, Clapper M, Myers GB. Endocarditis caused by the Micrococcus pharyngis siccus: Recovery after treatment with heparin and sulfapyridine. Am Heart J 1943;25:547-52.

${ }^{30}$ Schultz OT. Acute vegetative endocarditis with multiple secondary foci of involvement due to Micrococcus pharyngitidissiccae. JAMA 1918;71:1739-41.

${ }^{31}$ Coulter CB. Gram-negative micrococcus causing fatal endocarditis. Proc NY Pathol Soc 1915;15:7-12.

32 Dammin GJ. Subacute bacterial endocarditis caused by a hitherto undescribed Gram-negative coccus. Ann Intern Med 1941;15:756-65.

${ }^{33}$ Fainstein V, Musher DM, Young EJ. Purulent pericarditis due to Neisseria mucosa. Chest 1978;74:476-7.

${ }^{34}$ Noguchi TT, Nachum R, Lawrence CA. Acute purulent meningitis caused by chromogenic Neisseria. Med Arts Sci 1963;17:11-8.

${ }^{35}$ Sophian LH. A case of acute meningitis caused by Neisseria perflava. Am J Med Sci 1944;207:376-8.

${ }^{36}$ Benson H, Brennwasser R, D'andrea D. Neisseria subflava (Bergey) meningitis in an infant. J Infect Dis 1928;43:516-24.

${ }^{37}$ Lewin RA, Hughes WT. Neisseria subflava as a cause of meningitis and septicemia in children. JAMA 1966;195:821-3.

${ }^{38}$ Bansmer C, Brem J. Acute meningitis caused by Neisseria sicca. $N$ Engl J Med 1948;238:596-7.

${ }^{39}$ Newing WJ, Christie R. Meningitis: Isolation of an organism resembling Neisseria catarrhalis from cerebrospinal fluid. Med J Aust 1947;1:306-7.

${ }^{40}$ Pfister LE, Gallagher MV, Potterfield TG, Brown DW. Neisseria catarrhalis bacteremia with meningitis. JAMA 1965;193:399-401.

${ }^{41}$ Cocchi P, Ulivelli A. Meningitis caused by Neisseria catarrhalis. Acta Paediatr Scand 1968;57:451-3.

${ }^{42}$ Elston HR, Quigley HJ, Fitch DM. Meningitis due to Neisseria catarrhalis. Nebraska State Med J 1970;55:369-71.

${ }^{43}$ Arora S, Chitkara NL. Non-pathogenic Neisserian Neisseria catarrhalis as cause of meningitis. J Assoc Physicians India 1973;21:255-7.

44 Wilson WJ. A contribution to the bacteriology of cerebrospinal meningitis. Lancet 1908;i:1686-7.

${ }^{45}$ Garland J. A case of meningitis due to Micrococcus catarrhalis. Am J Dis Child 1923; 26:600-2.

${ }^{46}$ Moersch FP. Meningitis due to Micrococcus catarrhalis. Staff Meetings of the Mayo Clinic 1928;3:238-9.

${ }^{47}$ Berger U, Aboulkhair I, Rottmann W. Septicaemia and meningitis caused by Neisseria mucosa varietas heidelbergensis. Infection 1974;2:108-10.

${ }^{48}$ Cowan ST. Unusual infections following cerebral operations: with a description of Diplococcus mucosus. Lancet 1938;ii:1052-4.

${ }^{49}$ Bray PT, Cruickshank JC. Meningitis due to Diplococcus mucosus. Br Med J 1943; i:601-2.

${ }^{50}$ Bishop LK, Randall CC. Diplococcus mucosus meningitis successfully treated with sulfadiazine and penicillin. Am J Dis Child 1947;74:725-9.

${ }^{51}$ Lauer BA, Fisher CE. Neisseria lactamica meningitis. Am J Dis Child 1976;130:198-9.

52 Hansman D. Meningitis caused by Neisseria lactamica. $N$ Engl J Med 1978;299:491.

${ }^{53}$ Branham SE. A new meningococcus-like organism (Neiseria flavescens nsp) from epidemic meningitis. Public Health Rep 1930;45:845-9.

54 Prentice AW. Neisseria flavescens as a cause of meningitis. Lancet 1957;i:613-4.

${ }^{55}$ Reimann HA, Koucky RW. Meningitis caused by atypical Gramnegative cocci. J Bacteriol 1939;37:401-10.
${ }^{56}$ Edwards JL. An atypical Neisseria causing meningitis. $J$ Hyg 은 1944;43:328-9.

${ }^{57}$ Christie ALM, Cook GT. Fatal meningitis due to a capsulated $\overline{\overline{\bar{S}}}$ Neisseria. J Hyg 1947;45:149-50.

${ }^{58}$ Kippax PW, Saeed N, Pamplin WAV. An unusual Neisseria isolated from a case of meningitis. J Clin Pathol 1968;21:440-2. 을

${ }^{59}$ Muchmore HG, Venters HD. Purpura and septicemia due to $\frac{\bar{\rho}}{\widehat{T}}$ Neisseria subflava. N Engl J Med 1968;278:1166-7.

${ }^{\text {ov }}$ Feigin RD, Joaquin VS, Middelkamp JN. Purpura fulminans associated with Neisseria catarrhalis septicemia and meningitis. ڤ) Pediatrics 1969;44:120-3.

${ }^{61}$ Burnett AK, Easton DJ, Gordon AM, Rowan RM. Neisseria ${ }^{\circ}$ catarrhalis septicaemia in acute lymphoblastic leukaemia. Scott Med J 1975;20:37-8.

62 Thomson S, Gopaul D. Neisseria pharyngis septicaemia with associated disseminated intravascular coagulation. Can J Med Technol 1973;35:6-7.

${ }^{63}$ Wilson HD, Overman TL. Septicemia due to Neisseria lactamica. J Clin Microbiol 1976;4:214-5.

64 Wertlake PT, Williams TW. Septicaemia caused by Neisseria $\frac{N}{\omega}$ flavescens. J Clin Pathol 1968;21:437-9.

${ }^{65}$ Brorson J-E, Axelsson A, Holm SE. Studies on Branhamella 윽 catarrhalis (Neisseria catarrhalis) with special reference to $\rightarrow$ maxillary sinusitis. Scand J Infect Dis 1976;8:151-5.

${ }^{66}$ Coffey JD, Booth HN, Martin AD. Otitis media in the practice of $\mathscr{D}$ paediatrics: Bacteriological and clinical observations. Pediatrics 1966;38:25-32.

${ }^{67}$ Coffey JD, Martin AD, Booth HN. Neisseria catarrhalis in exudate otitis media. Arch Otolaryngol 1967;86:403-6.

${ }^{68}$ Kamme C, Lundgren K, Mårdh P-A. The aetiology of acute otitis $œ$ media in children. Scand J Infect Dis 1971;3:217-23.

${ }^{69}$ Lee W-S, Fordh. lactamase-producing Branhamella (Neisseria) catarrhalis. J오 Clin Microbiol 1981;13:222-3.

${ }^{70}$ Leinonen M, Luotonen J, Herva E, Valkonen K, Mäkelä PH. $\bar{\partial}$ Preliminary serologic evidence for a pathogenic role of Branhamella catarrhalis. J Infect Dis 1981;144:570-4.

${ }^{71}$ Schalén L, Christensen P, Kamme C, Miörner H, Pettersson K-I, Schalén C. High isolation rate of Branhamella catarrhalis from the nasopharynx in adults with acute laryngitis. Scand $J$ Infect 3 Dis 1980;12:277-80.

72 Johnson MA, Drew WL, Roberts M. Branhamella (Neisseria) catarrhalis-A lower respiratory tract pathogen? J Clin Microbiol 1981;13:1066-9.

${ }^{73}$ McNeely DJ, Kitchens CS, Kluge RM. Fatal Neisseria? (Branhamella) catarrhalis pneumonia in an immunodeficient $\frac{}{3}$ host. Am Rev Respir Dis 1976;114:399-402.

${ }^{74}$ Srinivasan G, Raff MJ, Templeton WC, Givens SJ, Graves RC, Melo JC. Branhamella catarrhalis pneumonia. Am Rev Respir Dis 1981;123:553-5.

${ }^{75}$ Ninane G, Joly P, Piot P, Kraytman M. Branhamella (Neisseria) 윽 catarrhalis as pathogen. Lancet 1977; ii:149.

${ }^{76}$ Ninane G, Joly J, Kraytman M. Bronchopulmonary infection due to Branhamella catarrhalis: 11 cases assessed by transtracheal puncture. Br Med J 1978;i;276-8.

$\pi$ Ninane G, Joly J, Kraytman M, Piot P. Bronchopulmonary infection due to $\beta$-lactamase-producing Branhamella catarrhalis treated with amoxycillin/clavulanic acid. Lancet 1978;ii:257. స్ట

${ }^{78}$ Percival A, Corkill JE, Rowlands J, Sykes RB. Pathogenicity of $\sigma$ and $\beta$-lactamase production by Branhamella (Neisseria) catarrhalis. Lancet 1977; ii:1175.

79 Alcid DV. Neisseria sicca pneumonia. Chest 1980;77:123-4.

80 Thorsteinsson SB, Minuth JN, Musher DM. Postpneumonectomy empyema due to Neisseria mucosa. Am J Clin Pathol 1975;64:534-6.

${ }^{81}$ Fisher LS, Edelstein P, Guze LB. Neisseria lactamicus pharyngitis. JAMA 1975;233:22.

82 Pykett AH. Isolation of Neisseria lactamicus from the nasopharynx. J Clin Pathol 1973;26:399-400.

83 Carpenter CM. Isolation of Neisseria fiava from the genitourinary 
tract of three patients. Am J Public Health 1943;33:135-6.

84 Wax L. The identity of Neisseria other than the gonococcus isolated from the genito-urinary tract. $J$ Vener Dis Inform 1950;31:208-13.

${ }^{85}$ Wilkinson AE. Occurrence of Neisseria other than the gonococcus in the genital tract. BrJ Vener Dis 1952;28:24-7.

8 Johnston J. Nongonococcal Neisserian strains isolated from the genitourinary tract. Am J Syph 1951;35:79-82.

${ }^{87}$ Weaver JD. Nongonorrheal vulvovaginitis due to Gram-negative intracellular diplococci. Am J Obstet Gynecol 1950;60:257-60.

88 Graber CD, Scott RC, Dunkelberg WE, Dirks KR. Isolation of Neisseria catarrhalis from three patients with urethritis and a clinical syndrome resembling gonorrhea. Am J Clin Pathol 1963;39:360-3.

${ }^{89}$ McCague JJ, McCague NJ, Altman CC. Neisseria catarrhalis urethritis: a case report. J Urol 1976;115:471.

${ }^{90}$ Blackwell C, Young H, Bain SSR. Isolation of Neisseria meningitidis and Neisseria catarrhalis from the genitourinary tract and anal canal. Br J Vener Dis 1978;54:41-4.

91 Jephcott AE, Morton RS. Isolation of Neisseria lactamicus from a genital site. Lancet 1972;ii:739-40.

${ }^{92}$ Brunton WAT, Young H, Fraser DRK. Isolation of Neisseria lactamica from the female genital tract. $B r J$ Vener Dis 1980;56:325-6.

${ }^{93}$ Coleman MB. An unusual strain of Neisseria isolated from the cervix uteri. J Vener Dis Inform 1946;27:159-60.
94 Schoolnik GK, Buchanan TM, Holmes KK. Gonococci causing disseminated gonococcal infection are resistant to the bactericidal action of normal human sera. J Clin Invest 1976;58:1163-73.

95 Johnson AP, Osborn MF, Taylor-Robinson D. Iron-mediated protection of Neisseria gonorrhoeae against killing by normal human serum. Fems Microbiol Lett 1978;4:225-7.

${ }^{9}$ Lee TJ, Schmayer A, Snyderman R, Yount WJ, Sparling PF. Familial deficiences of the sixth and seventh components of complement associated with bacteremic Neisseria infections. In: Brooks GF, Gotschlich EC, Holmes KK, Sawyer WD, Young FE, eds. Immunobiology of Neisseria gonorrhoeae. Washington DC: American Society for Microbiology, 1978:204-6.

97 Gould K, Ramirez-Ronda CH, Holmes RK, Sanford JP. Adherence of bacteria to heart valves in vitro. J Clin Invest 1975;56:1364-70.

98 Veale DR, Penn CW, Smith H. Capacity of gonococci to survive and grow within human phagocytes. In: Brooks GF, Gotschlich EC, Holmes KK, Sawyer WD, Young FE, eds. Immunobiology of Neisseria gonorrhoeae. Washington DC: American Society for Microbiology, 1978:227-31.

Requests for reprints to : Dr AP Johnson, Division of Communicable Diseases, Clinical Research Centre, Watford Road, Harrow, Middlesex HA1 3UJ. England. 